\title{
Author Correction: Higher ambient synaptic glutamate at inhibitory versus excitatory neurons differentially impacts NMDA receptor activity
}

\author{
Lulu Yao ${ }^{1}$, Teddy Grand ${ }^{2}$, Jesse E. Hanson ${ }^{3}$, Pierre Paoletti ${ }^{2} \&$ Qiang Zhou ${ }^{1}$
}

Correction to: Nature Communications; https://doi.org/10.1038/s41467-018-06512-7, published online 01 October 2018

The original version of this Article omitted the middle initial of the author Jesse E. Hanson. This has now been corrected in both the PDF and HTML versions of the Article.

Published online: 15 November 2018

\begin{abstract}
(c) (i) Open Access This article is licensed under a Creative Commons Attribution 4.0 International License, which permits use, sharing, adaptation, distribution and (C) reproduction in any medium or format, as long as you give appropriate credit to the original author(s) and the source, provide a link to the Creative Commons license, and indicate if changes were made. The images or other third party material in this article are included in the article's Creative Commons license, unless indicated otherwise in a credit line to the material. If material is not included in the article's Creative Commons license and your intended use is not permitted by statutory regulation or exceeds the permitted use, you will need to obtain permission directly from the copyright holder. To view a copy of this license, visit http://creativecommons.org/licenses/by/4.0/.
\end{abstract}

(c) The Author(s) 2018

\footnotetext{
${ }^{1}$ School of Chemical Biology and Biotechnology, Peking University Shenzhen Graduate School, 518055 Shenzhen, China. ${ }^{2}$ Institut de Biologie de I'Ecole Normale Supérieure (IBENS), Ecole Normale Supérieure, CNRS, INSERM, Université PSL, 46 rue d'Ulm, 75005 Paris, France. ${ }^{3}$ Department of Neuroscience, Genentech, Inc., South San Francisco 94080 CA, USA. Correspondence and requests for materials should be addressed to

Q.Z. (email: zhouqiang@pkusz.edu.cn)
} 